\title{
Lithofacies characteristics and its effect on gas storage of the Silurian Longmaxi Marine Shale in the southeast Sichuan Basin, China
}

\begin{abstract}
Based on a detailed description and analysis of outcrops and drilling cores, onsite gas desorption, and laboratory testing data, shale lithofacies characteristics and its effect on gas storage of the Silurian Longmaxi Formation marine shale in the southeast Sichuan Basin have been studied. Twelve types of shale lithofacies are classified based on the organic matter content and mineral composition, of which 9 types were identified in the study area based on their dramatically differences in color, grain size, lamination, organic matter content, mineralogy, density, and other physical properties. The bottom of the Longmaxi shale Formation is primarily organic-rich siliceous shale with stable distribution of thickness and good continuity. The upper section has characteristics of rapid vertical and lateral change in lithofacies, exhibiting a strong spatial heterogeneity. Organic-rich siliceous shale in the lower section, showing the highest content of gas desorption in situ, has a high content of organic matter, a high brittleness index and good permeability, which is conducive to shale gas storage, hydraulic fracturing, and exploitation. Organic-rich argillaceous shale was also observed to have the highest methane adsorption capacity. The interval with lithofacies association of organic-rich siliceous shale with organic-rich argillaceous shale interlayer is the pay zone for shale gas generation and accumulation.
\end{abstract}

Keywords: Sichuan Basin; Longmaxi Formation; shale lithofacies; organic-rich siliceous shale; gas storage. 


\section{Introduction}

In recent years, the exploration of shale gas has been conducted in an orderly fashion in China. The exploration practice shows that the reservoir characteristics are important for shale gas accumulation. However, the key to the study of reservoir characteristics is to identify favorable lithofacies for commercial development (Jacobi et al., 2008; Sahoo et al, 2014). Due to the strong heterogeneity of shale reservoirs from the macro-scale to micro-scale, it is difficult to predict effective shale gas reservoirs (Chen et al., 2015; Jiang et al., 2015). Thus, a new method should be used to comprehensively evaluate shale gas reservoirs to accurately characterize their geochemistry, mineralogy, petrology, petrophysics and gas storage potential. Elucidating these features is important for predicting productive shale lithofacies. The lithofacies is the basic unit that constitutes a shale reservoir, reflecting geochemical, geological and petrophysicsal information. Every typical lithofacies reflects the characteristics of one type of shale reservoir with a relatively high level of homogeneity (Slatt and Rodriguez, 2012). Thus, studying lithofacies is one effective method of evaluating a shale reservoir and studying the main controlling factors of shale gas accumulation. Systemic investigation on the characteristics of lithofacies, such as the distribution of mineral composition, content of organic matter, gas storage potential, and the relationship between lithofacies and gas content, would benefit shale gas exploration and development (Abouelresh and Slatt, 2012; Rivard et al.,2014).

Eberzin (1940) first used the term "lithofacies" in geology to describe the lithological characteristics of sedimentary rock. The lithofacies characteristics could be described by partially qualitative and partially quantitative parameters, including mineral composition, texture, structure, bedding, color, size distribution, roundness and sorting (Dill et al., 2005). Before the successful development of shale gas, studies of lithofacies focused on conventional sandstone and carbonate reservoirs, which reflect their sedimentary setting and process. However, the understanding of shale lithofacies remains poor (Wang and Carr, 2012; Slatt et al., 2014).

At present, many studies on the lithofacies of shale reservoirs have been carried out, mainly focusing on the Barnett Shale and Marcellus shale (Loucks and Ruppel, 2007; Singh, 2008; Wang and Carr, 2012). In China, the studies of shale lithofacies have just begun, and much important information has been accumulated, mainly focusing on a qualitative description of the outcrops and drilling cores. For instance, shale was classified into categories including carbonaceous shale, siliceous shale, silty shale, and calcareous shale and described extensively (Du et al., 2014; Tan et al., 2014; Chen et al., 2015). These studies are of great significance for understanding the sedimentary process and setting of shale and characterizing shale reservoirs. As shale is a fine-grained sediment and poorly exposed on surface, it is very difficult to describe outcrops, resulting in an ineffective classification of shale lithofacies (Hughes and Thomas, 2011). In addition, some shales comprise a high content of expandable clay minerals, which would be easily reactive to water, resulting in swelling and deformation and a difficulty of making thin section as well as great difficulty of microscopic description. Due to different research objectives and laboratory methods, different definitions and classification criteria for shale lithofacies, there have been too many complex classifications of shale lithofacies (Schieber and Zimmerle, 1998). Thus, it is necessary to choose an appropriate, simple and 
practical approach to scientifically classify shale lithofacies to reflect their mineral composition, texture, structure, content of organic matter, gas storage potential and geomechanical properties.

The purpose of this paper is to scientifically classify shale lithofacies based on sample description and analysis of sample tests of rock properties and gas content, and then to investigate the characteristics of each shale lithofacies of the Silurian Longmaxi Formation in the southeastern Sichuan Basin and their control of its gas storage potential. All samples of the Silurian Longmaxi Shale were from outcrops and drill cores from CY 1 to CY 6 wells in the southeast Sichuan Basin, China (Figure 1).

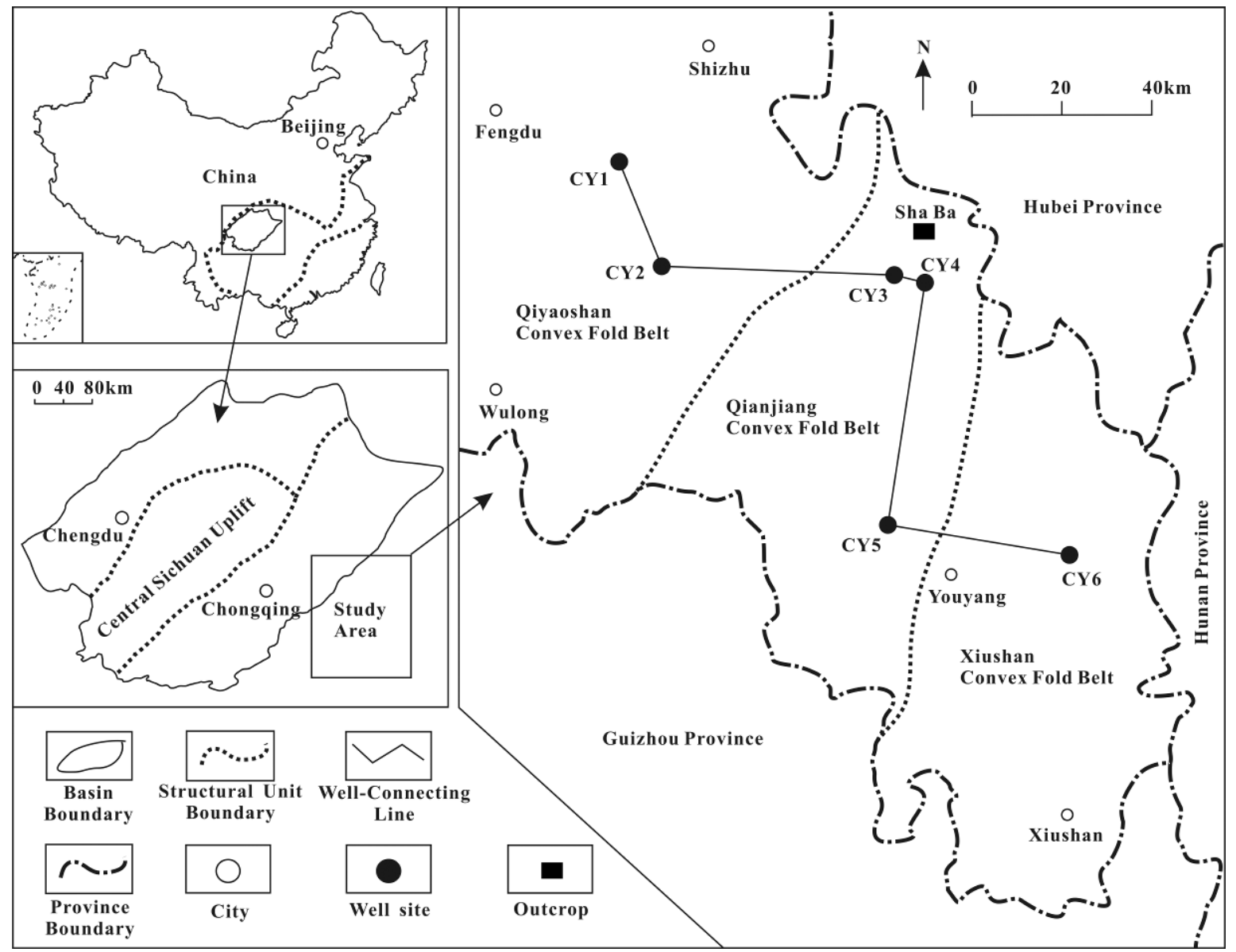

Figure 1 Tectonic division of study area and well locations in the southeast Sichuan Basin.

\section{Theory}

\subsection{Selection of lithofacies parameters}

Shale gas exploration and development in North America shows that the analysis of shale lithofacies is the key to evaluating shale gas reservoir volume, fracturing, and gas productivity (Hickey and Henk, 2007). It is an effective technology to recognize favorable targets at the regional or basin scale (Loucks and Ruppel, 2007). Thus, the classification of shale lithofacies should be capable of reflecting gas storage capacity, horizontal fracturing effect and gas flow capacity in shale (Wang and Carr, 2012).

The shale gas storage capacity has a good positive correlation with the organic matter richness. Shale reservoirs with high total organic carbon (TOC) content have relatively high gas adsorption capacity, representing high gas storage potential (Chalmers and Bustin, 2008). Exploration in the 
southeastern Sichuan Basin shows that shale samples with a TOC content greater than 2 wt. \% have a get gas content close to in situ condition. Hence, organic matter is regarded as an important parameter for the classification of shale lithofacies.

The effectiveness of hydraulic fracturing is mainly controlled by geomechanical properties, which are closely related to mineral composition (Jarvie et al., 2007). Compared to clay minerals, the high content of quartz and carbonate would improve the fracability of shale, resulting in the easier generation and propagation of a widespread complex fracture network (Rickman et al., 2008; Sondergeld et al., 2010). Thus, mineral composition should be considered in the classification of shale lithofacies to reflect the geomechanical properties.

The shale gas flow capacity is mainly determined by the development situation and the connectivity of the pores in shale (Slatt and O'Brien, 2011). However, these parameters are closely related to the mineral composition and content of organic matter of the shale (Jiang et al., 2015). Organic matter tends to contribute the development of many nanoscale pores, while minerals mainly develop microscale and nanoscale pores (Tang et al., 2015). For shale with the same maturity, the shale gas storage potential and the ratio of free gas to absorbed gas are related to the content of organic matter and mineral composition (Wang and Carr, 2012). Thus, shale lithofacies can reflect the gas flow capacity through considering organic matter and the mineral composition.

Therefore, the critical criteria for defining shale lithofacies should include organic matter and inorganic mineral composition instead of texture, bedding, structure, and particle size distribution. Shale lithofacies divided based on the organic matter richness and mineral composition could effectively reflect the quality of shale reservoirs. Furthermore, the content of organic matter and mineral composition could be easily and accurately obtained through consistent experiments using same instruments in the same labs.

\subsection{Definition of lithofacies parameters}

The threshold of hydrocarbon generation in shale remains controversial. Schmoker (1981) and Peters and Cassa (1994) suggested that shale with a TOC greater than 2 wt. \% has good hydrocarbon generation potential. Jarvie (1991) noted that shale with a TOC $>1$ wt. \% could be of sufficient hydrocarbon generation potential to be regarded as an effective source rock. Bowker (2007) argued that a TOC of at least 2.5 wt. \%-3.0 wt. \% was necessary in commercial shale gas fields. Burnaman et al. (2009) showed that a shale reservoir should have a TOC of at least 2 wt. \%. The Longmaxi Formation marine shale in southern China consists mainly of type I kerogen, which is at the over-mature stage, leading to obvious differences between the contents of original organic matter and remnant organic matter, presenting an effective shale reservoir with a remnant organic matter of approximately 1 wt. \% (Chen et al., 2011). In the southeastern Sichuan Basin, samples with TOC $>1$ wt. \% are generally gasbearing proven by onsite gas desorption experiments, and those with TOC $>2$ wt. \% are generally measured to have gas desorption contents of greater than $1 \mathrm{~m}^{3} / \mathrm{t}$ (Guo and Zhang., 2014). Furthermore, with a TOC $>2$ wt. $\%$, the shale porosity is mainly contributed by organic pores rather than inorganic pores, and the shale gas exists mainly as absorbed gas state (Tang et al., 2015). Therefore, taking the TOC contents of 1 wt. $\%$ and 2 wt. $\%$ as demarcations for lithofacies classification is reasonable. 
When the content of clay minerals is greater than $40 \%$, the shale generally shows plasticity (Jarvie

et al., 2007). Although a high content of clay minerals could favor shale gas adsorption, it is disadvantageous for shale fracturing. Shale consisting mainly of clay minerals also presents relatively strong homogeneity (Wang and Carr, 2012). Thus, shale of a clay mineral content of greater than $40 \%$ is considered argillaceous shale.

With a clay mineral content of less than $40 \%$, shale is brittle, which is favorable for hydraulic fracturing. The influences of calcareous and siliceous minerals on the shale properties also become significant. The shale properties are actually the composite results of different types of minerals (Jiang et al., 2015). When $\mathrm{Ca} / \mathrm{Si}>2$, calcareous minerals prevail, indicating a warm and shallow water sedimentary setting, which is disadvantageous for the preservation of organic matter (Lewy et al., 2011). When $\mathrm{Ca} / \mathrm{Si}<1 / 2$, siliceous minerals prevail, indicating a relatively deep and reductive water sedimentary environment, which is favorable for the preservation of organic matter. Furthermore, the high content of siliceous minerals indicates relatively high brittleness, also favorable for hydraulic fracturing during the exploitation of shale gas (Jarvie, 2007). A high content of quartz favors the development of macro-pores (diameter $>50 \mathrm{~nm}$ ), so that it also helps improve the shale gas flow capacity (Tang et al., 2015). When $1 / 2<\mathrm{Ca} / \mathrm{Si}<2$, the contents of siliceous minerals and calcareous minerals are almost equal, which is favorable for the preservation of organic matter and hydraulic fracturing.

\subsection{Twelve types of shale lithofacies}

As shown in Figure 2, based on the TOC content, shale could be divided into three types: organicrich shale (TOC $>2 \mathrm{wt} . \%)$, organic-fair shale $(2 \mathrm{wt} . \%>\mathrm{TOC}>1 \mathrm{wt} . \%)$, and organic-poor shale (TOC $<1$ wt.\%). Based on the contents of quartz ( $\mathrm{Si}$ ), clay, and carbonate $(\mathrm{Ca})$, shale could be classified into four types: argillaceous shale (I, clay $>40 \%$ ), calcareous shale (II, clay $<40 \%, \mathrm{Ca} / \mathrm{Si}>2$ ), mixed shale (III, clay $<40 \%, 1 / 2<\mathrm{Ca} / \mathrm{Si}<2$ ), and siliceous shale (IV, clay $<40 \%, \mathrm{Ca} / \mathrm{Si}<1 / 2$ ) (Figure 2).

Combining the three types divided by TOC content and four types divided by mineral composition, twelve lithofacies classification could be obtained: organic-rich argillaceous shale, organic-rich calcareous shale, organic-rich mixed shale, organic-rich siliceous shale, organic-fair argillaceous shale, organic-fair calcareous shale, organic-fair mixed shale, organic-fair siliceous shale, organic-poor argillaceous shale, organic-poor calcareous shale, organic-poor mixed shale, and organic-poor siliceous shale. 


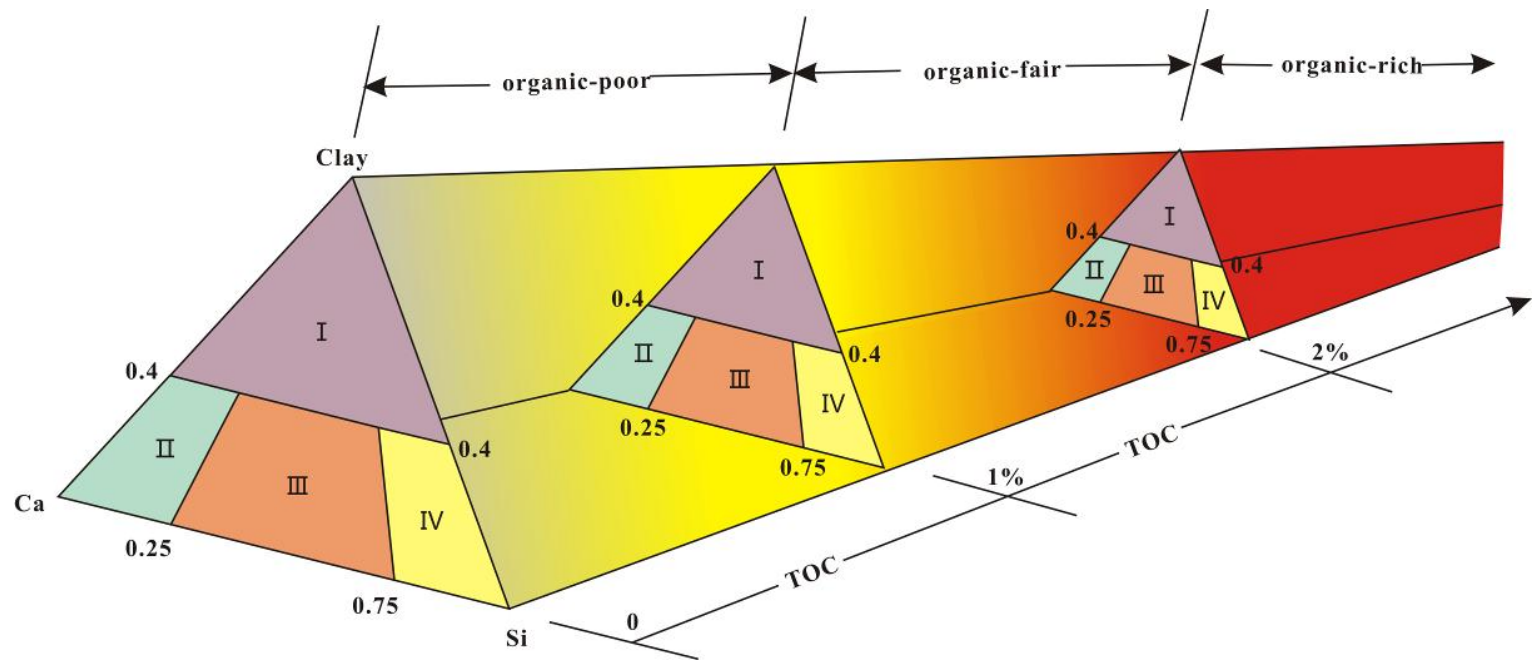

Figure 2 Classification of shale lithofacies. Clay: clay minerals; Ca: carbonates, mainly comprising calcite and dolomite; Si: quartz; I: argillaceous shale; II: calcareous shale; III: mixed shale; IV: siliceous shale.

\subsection{Shale lithofacies in the study area}

Applying the classification of shale lithofacies to the Silurian Longmaxi Shale in the southeast Sichuan Basin, a total of 9 types of lithofacies were identified in the study area based on the analysis of the TOC content and mineral composition of 185 samples from 6 wells (Figure 3, Table 1). The Silurian Longmaxi Formation shale in the study area mainly comprises quartz and clay minerals and minor calcareous minerals. Organic-rich shale with TOC $>2$ wt. $\%$ generally has a high content of quartz (Figure 3). Organic-fair shale mainly consists of clay minerals. Mixed shale with a high content of calcareous minerals generally has a low TOC, possibly due to its sedimentary setting (Lewy et al., 2011).

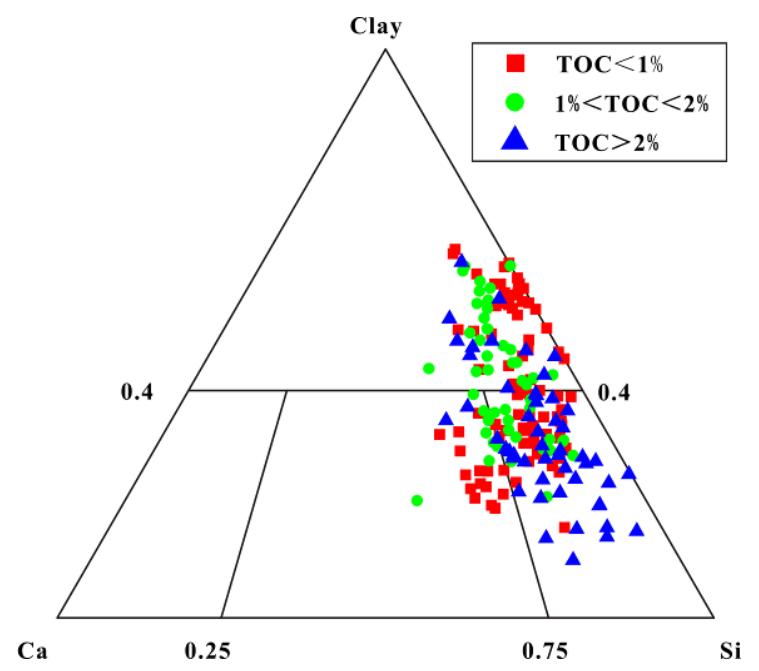

Figure 3 Ternary diagram showing mineral composition and TOC content of the Longmaxi Formation Shale in the southeast Sichuan Basin. Organic-rich shale $=$ TOC $>2 \%$, organic-fair shale $=1 \%<\mathrm{TOC}<2 \%$, and organic-poor shale $=\mathrm{TOC}<1 \%$.

Table 1 Statistics of shale lithofacies of the Longmaxi Formation Shale in the southeast Sichuan Basin.

\begin{tabular}{ccc}
\hline Type & Abbreviation & Sample quantity \\
\hline Organic-rich siliceous shale & ORSS & 37 \\
Organic-rich mixed shale & ORMS & 3 \\
Organic-rich argillaceous shale & ORAS & 11 \\
\hline
\end{tabular}




\section{Results}

\begin{tabular}{clc}
\hline Organic-fair siliceous shale & OFSS & 15 \\
Organic-fair mixed shale & OFMS & 8 \\
Organic-fair argillaceous shale & OFAS & 27 \\
Organic-poor siliceous shale & OPSS & 36 \\
Organic-poor mixed shale & OPMS & 15 \\
Organic-poor argillaceous shale & OPAS & 38 \\
\hline
\end{tabular}

\subsection{Petrologic characteristics}

From Table 2, the petrologic characteristics of the 9 types of lithofacies in the study area are very different. Generally, ORSS, ORMS and ORAS have a high TOC content, a relatively low density and poor porosity and permeability, presenting as black without obvious lamina, and commonly have graptolite and pyrite. ORSS has the highest TOC content and well-developed micro- and nano- pores, conducive for shale gas richness. Additionally, due to the high brittleness index resulting from a high content of quartz, ORSS is favorable for hydraulic fracturing. Furthermore, due to its relatively high porosity and permeability, ORSS is favorable for gas flow. OFSS, OFMS, and OFAS have fewer differences in shale lithofacies, presenting similar pyrite and graptolite contents, exhibiting lamina and having relatively good porosity and permeability. However, OPSS, OPMS, and OPAS present as gray due to their low content of organic matter, characterized by obvious minerals and bedding, which have horizontal bedding and ripple bedding with poor connectivity and a dramatic change in porosity and permeability. 
Table 2 Petrologic characteristics of the Longmaxi Formation Shale in the southeast Sichuan Basin.

\begin{tabular}{|c|c|c|c|c|c|c|c|c|c|c|}
\hline \multirow{2}{*}{ Type } & \multicolumn{3}{|c|}{ Macro-scale to Micro-scale } & \multirow{2}{*}{\multicolumn{2}{|c|}{$\begin{array}{c}\text { Mineral Composition } \\
\text { Average }(\%)\end{array}$}} & \multirow{2}{*}{$\begin{array}{l}\text { Density } \\
\text { (Range/ } \\
\text { average, } \\
\mathrm{g} / \mathrm{cm}^{3} \text { ) }\end{array}$} & \multirow{2}{*}{$\begin{array}{l}\text { Brittleness } \\
\text { Index } \\
\text { (Range/ } \\
\text { average) }\end{array}$} & \multirow{2}{*}{$\begin{array}{l}\text { Effective } \\
\text { Porosity } \\
\text { (Range/ } \\
\text { average, \%) }\end{array}$} & \multirow{2}{*}{$\begin{array}{c}\text { Permeability } \\
\text { (Range/ } \\
\text { average, } \mathrm{mD})\end{array}$} & \multirow{2}{*}{$\begin{array}{l}\text { Sample } \\
\text { quantity }\end{array}$} \\
\hline & Drilling Core & Thin Section & FE-SEM & & & & & & & \\
\hline $\begin{array}{l}\text { Organic-rich } \\
\text { siliceous } \\
\text { shale } \\
\text { (ORSS) }\end{array}$ & & & & $\begin{array}{c}\text { Quartz: } \\
\text { Feldspar: } \\
\text { Carbonates: } \\
\text { Clay Minerals: } \\
\text { Pyrite: } \\
\text { TOC: }\end{array}$ & $\begin{array}{c}54.2 \\
9.5 \\
8.6 \\
22.5 \\
3.9 \\
3.7\end{array}$ & $\frac{2.43-2.75}{2.62}$ & $\frac{0.53-0.81}{0.63}$ & $\frac{0.11-5.61}{1.61}$ & $\frac{0.0001-0.1674}{0.0267}$ & 37 \\
\hline $\begin{array}{l}\text { Organic-rich } \\
\text { mixed shale } \\
(\text { ORMS })\end{array}$ & & & & $\begin{array}{c}\text { Quartz: } \\
\text { Feldspar: } \\
\text { Carbonates: } \\
\text { Clay Minerals: } \\
\text { Pyrite: } \\
\text { TOC: }\end{array}$ & $\begin{array}{c}36.5 \\
14.4 \\
15.9 \\
27.6 \\
4.2 \\
2.3\end{array}$ & $\frac{2.60-2.65}{2.62}$ & $\frac{0.42-0.51}{0.46}$ & $\frac{0.15-1.28}{0.82}$ & $\frac{0.0003-0.0003}{0.0003}$ & 3 \\
\hline $\begin{array}{c}\text { Organic-rich } \\
\text { argillaceous } \\
\text { shale } \\
\text { (ORAS) }\end{array}$ & & & & $\begin{array}{c}\text { Quartz: } \\
\text { Feldspar: } \\
\text { Carbonates: } \\
\text { Clay Minerals: } \\
\text { Pyrite: } \\
\text { TOC: }\end{array}$ & $\begin{array}{c}35.6 \\
11.3 \\
7.6 \\
41.2 \\
3.8 \\
2.6\end{array}$ & $\frac{2.58-2.71}{2.63}$ & $\frac{0.30-0.53}{0.42}$ & $\frac{0.11-4.46}{1.10}$ & $\frac{0.0001-0.0321}{0.0032}$ & 11 \\
\hline $\begin{array}{l}\text { Organic-fair } \\
\text { siliceous } \\
\text { shale } \\
\text { (OFSS) }\end{array}$ & & & & $\begin{array}{c}\text { Quartz: } \\
\text { Feldspar: } \\
\text { Carbonates: } \\
\text { Clay Minerals: } \\
\text { Pyrite: } \\
\text { TOC: }\end{array}$ & $\begin{array}{c}44.5 \\
17.0 \\
9.2 \\
25.1 \\
3.3 \\
1.4\end{array}$ & $\frac{2.53-2.83}{2.67}$ & $\frac{0.48-0.64}{0.57}$ & $\frac{0.11-2.85}{0.99}$ & $\frac{0.0001-6.4323}{0.4612}$ & 15 \\
\hline $\begin{array}{l}\text { Organic-fair } \\
\text { mixed shale } \\
\text { (OFMS) }\end{array}$ & & & & $\begin{array}{c}\text { Quartz: } \\
\text { Feldspar: } \\
\text { Carbonates: } \\
\text { Clay Minerals: } \\
\text { Pyrite: }\end{array}$ & $\begin{array}{c}36.7 \\
17.6 \\
15.1 \\
23.9 \\
4.0 \\
\end{array}$ & $\frac{2.71-2.74}{2.73}$ & $\frac{0.44-0.52}{0.48}$ & $\frac{0.12-1.71}{0.78}$ & $\frac{0.0001-0.0121}{0.0011}$ & 8 \\
\hline
\end{tabular}




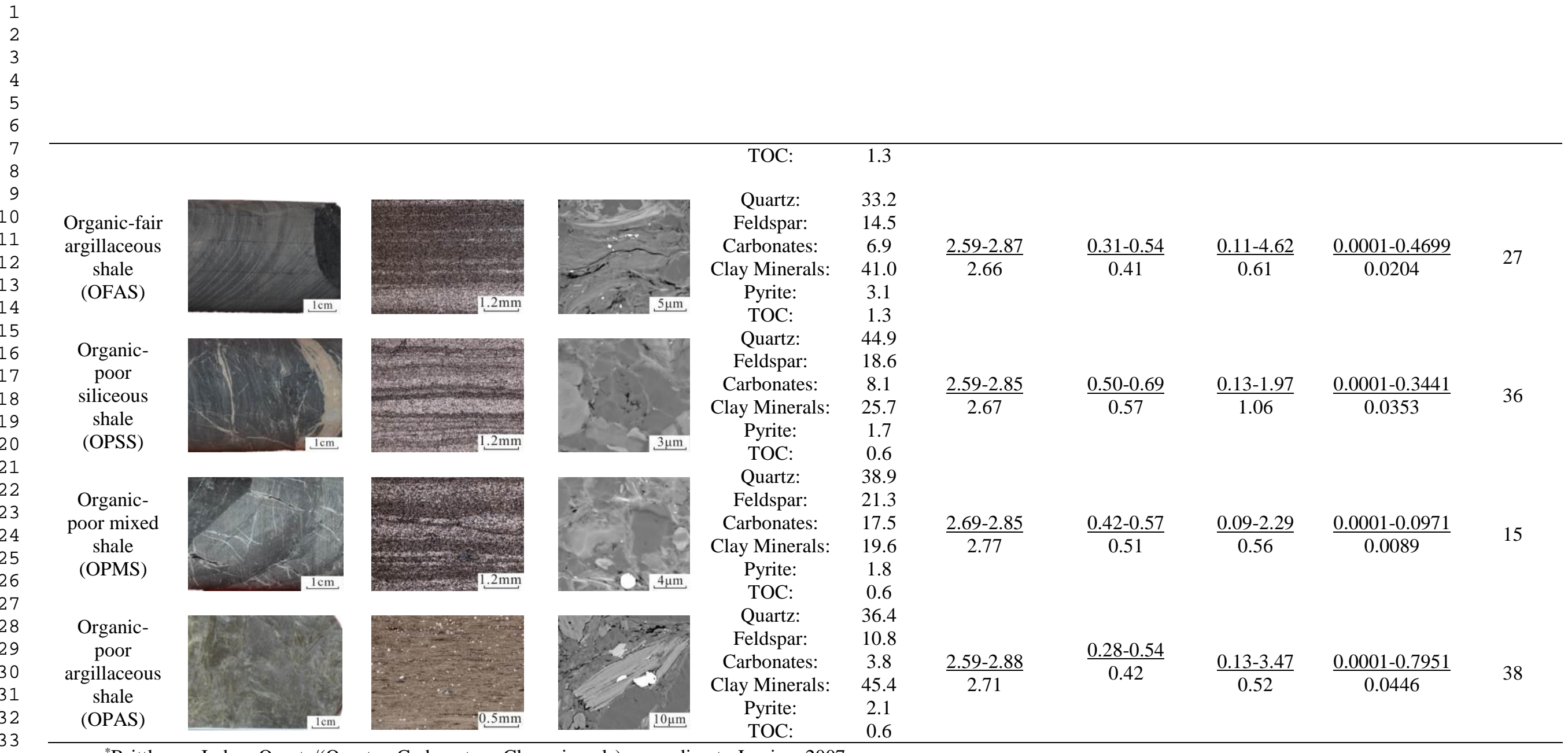

"Brittleness Index=Quartz/(Quartz+ Carbonates+ Clay minerals), according to Jarvie, 2007. 


\subsection{Characteristics of spatial distribution}

Based on data from outcrops, drilling cores, well logging and laboratory testing, the characteristics of the spatial distribution of the Silurian Longmaxi Formation Shale in the southeast Sichuan Basin were studied. As shown in Figure 4, the shale lithofacies change dramatically in the vertical direction. The Silurian Longmaxi Formation Shale consists mainly of ORAS, OFSS and OPSS. ORAS and ORMS are usually present as thin interlayers with thickness of less than 1 meter, which is hardly seen in Figure 4. At the bottom of the Silurian Longmaxi Formation, where the ORSS is mainly developed. The content of TOC decreases and the content of clay minerals increases from bottom to top, resulting in shale lithofacies gradually evolving into mixed shale and argillaceous shale at the upper section from siliceous shale at the lower section. At the top of the Silurian Longmaxi Formation, various types of shale lithofacies are present, representing relatively high heterogeneity.

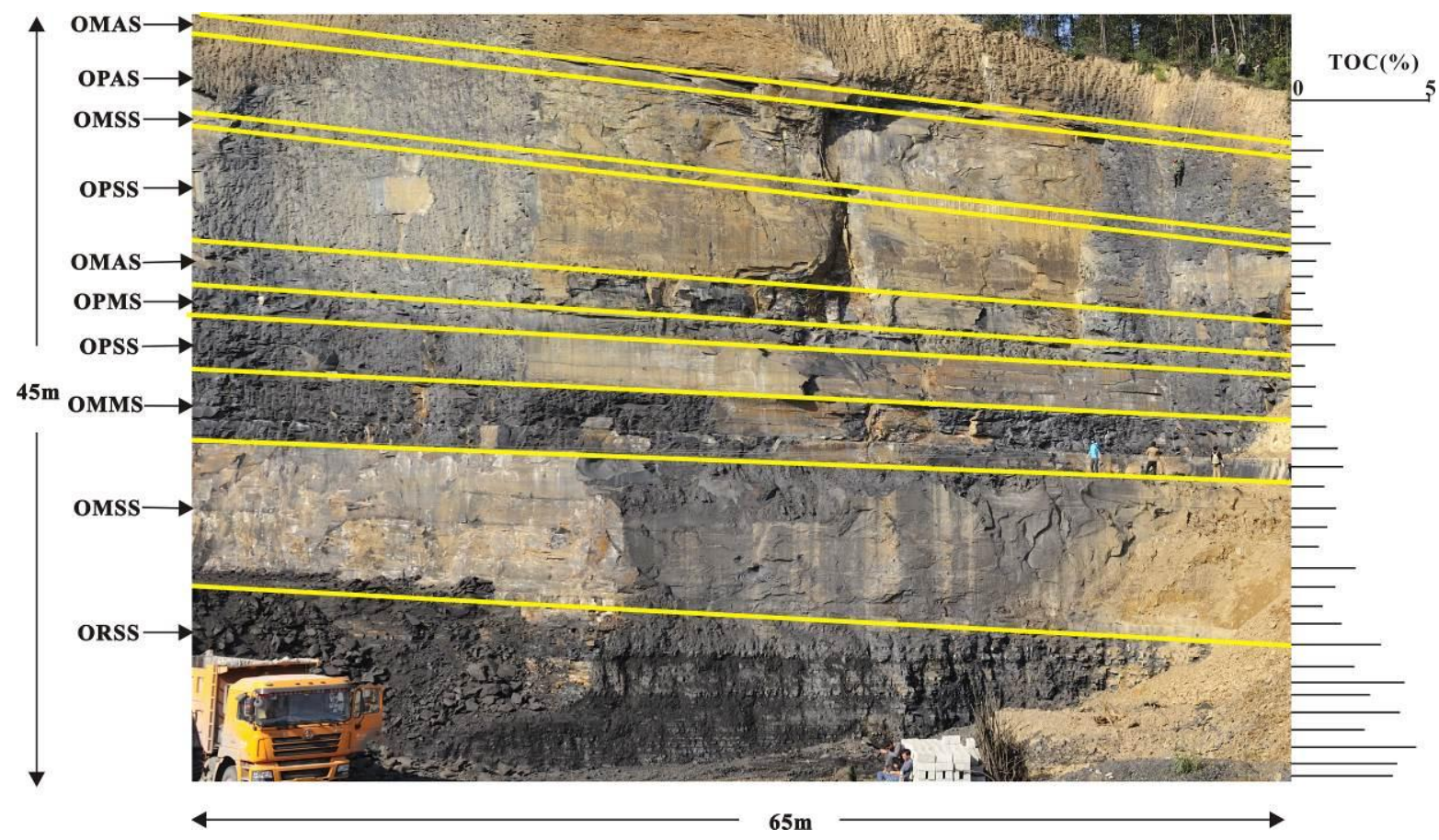

Figure 4 Characteristics of shale lithofacies of the Shaba outcrop in the southeast Sichuan Basin. See

Figure 1 for the outcrop location.

Based on the shale lithofacies analysis of wells and outcrops in the study area, a NW-SE crosssection was generated to study the distribution and connectivity of the shale lithofacies (Figure 5). The ORSS at the bottom of the Longmaxi Formation has a stable distribution in thickness and good connectivity, characterized by a gradual decrease of thickness from NW to SE. In contrast, the middle and upper parts of the Longmaxi Formation have a rapid change in the shale lithofacies in the vertical direction and poor lateral connectivity, representing relatively high spatial heterogeneity, which increases the difficulty of predicting the spatial distribution of shale lithofacies. 


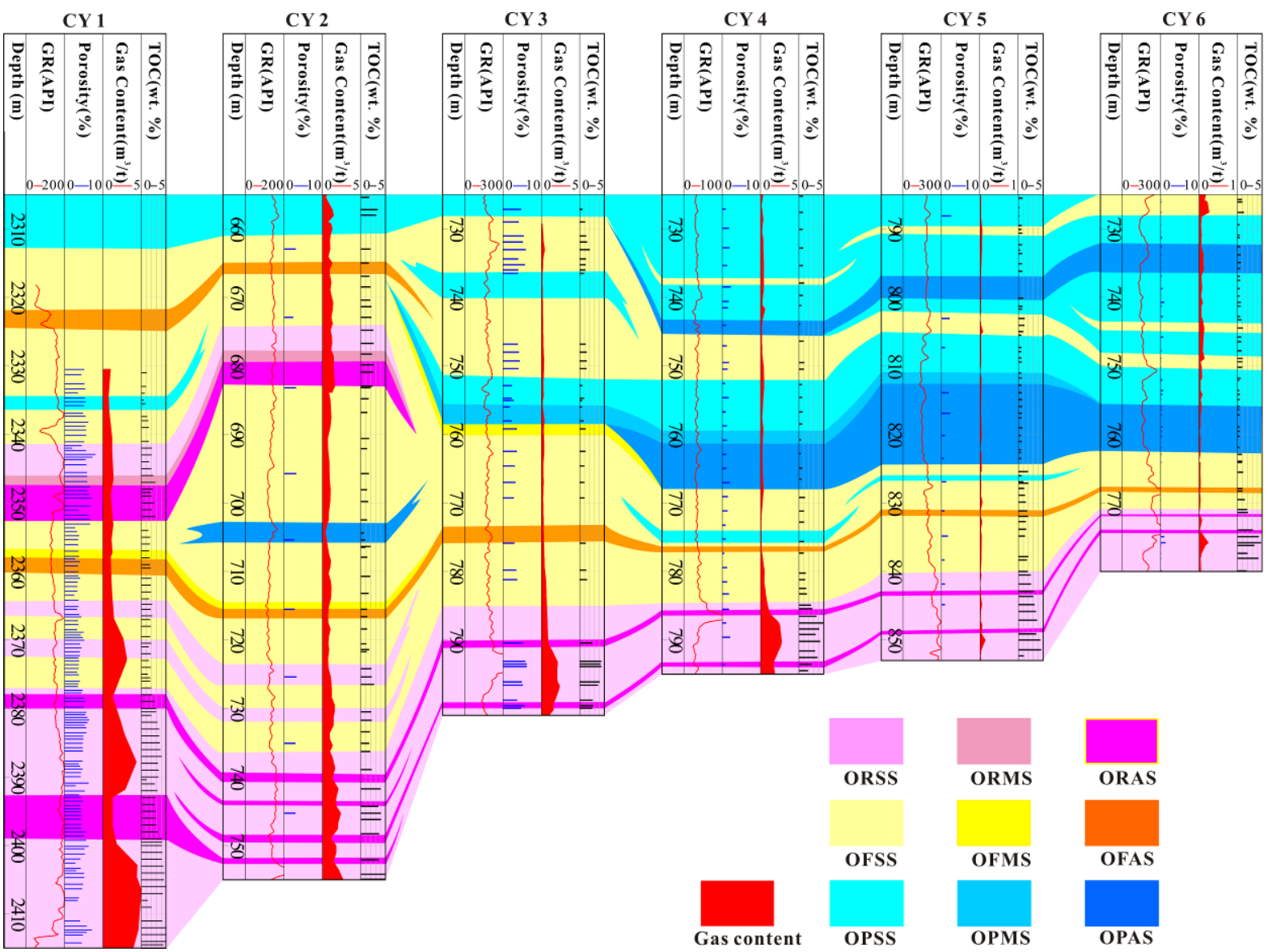

Figure 5 NW-SE cross-section of the Longmaxi Formation Shale in the southeast Sichuan Basin, showing the correlation of the different lithofacies and indicating the ORSS interbedded with ORAS in the lower section has the highest gas content. See Figure 1 for the location of the cross section.

\section{Shale gas content in different lithofacies}

$\mathrm{CH}_{4}$ adsorption experiments in the lab and gas desorption experiments in situ are useful technologies to investigating the shale gas storage capacity. Through $\mathrm{CH}_{4}$ adsorption experiments in the lab, the gas adsorption capacity of each shale lithofacies could be obtained. Through onsite gas desorption experiments, the gas content of each shale lithofacies under realistic geological conditions could be investigated. To ensure the comparability of the data from the onsite gas desorption experiments, all the data are from Well CY2.

\subsection{Effect of lithofacies on shale gas content in subsurface conditions}

The results of gas desorption experiments in situ of 68 samples from Well CY2 showed that ORSS has the highest gas content, with an average of $1.6 \mathrm{~m}^{3} / \mathrm{t}$; the second is ORMS, with an average of $1.4 \mathrm{~m}^{3} / \mathrm{t}$; and OPMS has the lowest, with an average of $0.2 \mathrm{~m}^{3} / \mathrm{t}$ (Figure 6). Generally, ORSS, ORMS and ORAS have relatively high content of organic matter, which are favorable for methane accumulation as free and adsorbed state since the organic matter at the high-maturity stage would provide many organic pores and adsorb gas itself (Chen et al., 2014). As shown in Figure 7, the content of organic matter shows a good positive correlation with the gas desorption content, indicating that organic matter plays an important role in determining the subsurface shale gas content. Furthermore, for the organic-rich shale, the gas desorption content increases with the increasing content of siliceous 
minerals, which is perhaps related to the good coupling relationship between quartz and organic matter (Huang et al., 2012). Therefore, ORSS, ORMS and ORAS are most favorable for shale gas storage, while OPSS, OPMS and OPAS are disfavor shale gas storage.

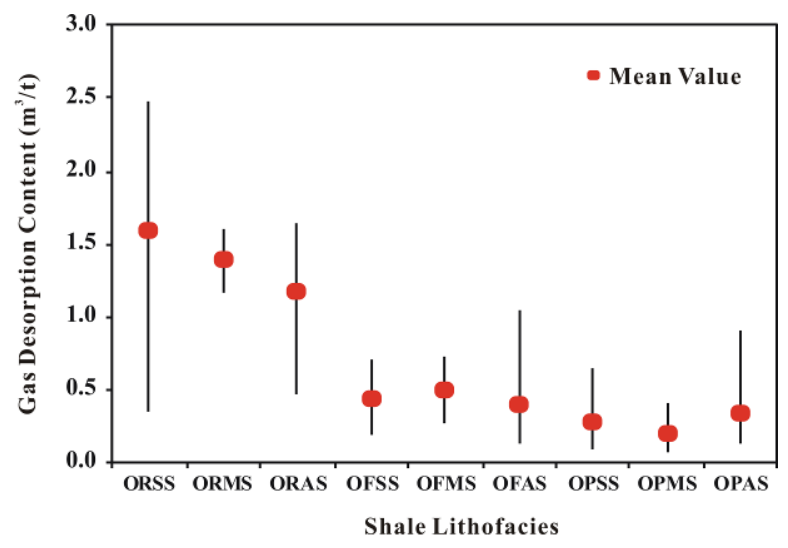

Figure 6 Gas content of different shale lithofacies in Well CY2 through onsite gas desorption experiments, showing the ORSS has the highest gas content.

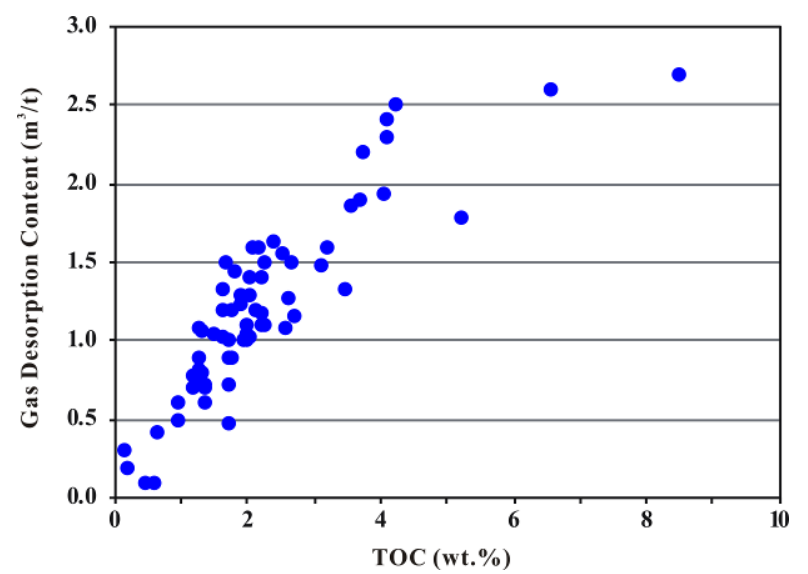

Figure 7 Relationship between TOC and gas desorption content of shale in Well CY2, showing a good positive correlation.

\subsection{Effect of lithofacies on shale gas adsorption capacity}

Three samples from each type of lithofacies in the study area were chosen for $\mathrm{CH}_{4}$ adsorption experiments. The methane adsorption experiment $\left(30^{\circ} \mathrm{C}\right.$; up to $\left.35 \mathrm{MPa}\right)$ was conducted according to the Chinese National Standard GB/T 19560-2004 at the State Key Laboratory of Petroleum Resource and Prospecting of the China University of Petroleum, Beijing. The results revealed that ORAS has the largest amount of adsorbed methane, on average $8.5 \mathrm{~m}^{3} / \mathrm{t}$. The second highest is ORMS, with an average of $6.0 \mathrm{~m}^{3} / \mathrm{t}$, and the third is OFAS, with an average of $5.0 \mathrm{~m}^{3} / \mathrm{t}$. In contrast, OPSS has the lowest amount of adsorbed methane, on average $1.5 \mathrm{~m}^{3} / \mathrm{t}$ (Figure 8). For the lithofacies with similar mineral compositions, the higher the content of organic matter, the higher the amount of absorbed methane. For the lithofacies with similar contents of organic matter, the higher the content of clay minerals, the higher the amount of absorbed methane. Thus, the 9 types of lithofacies have different methane adsorption capacities, as they have distinct contents of organic matter and mineral compositions. High contents of organic matter and clay minerals both contribute to the capacity for methane adsorption. 

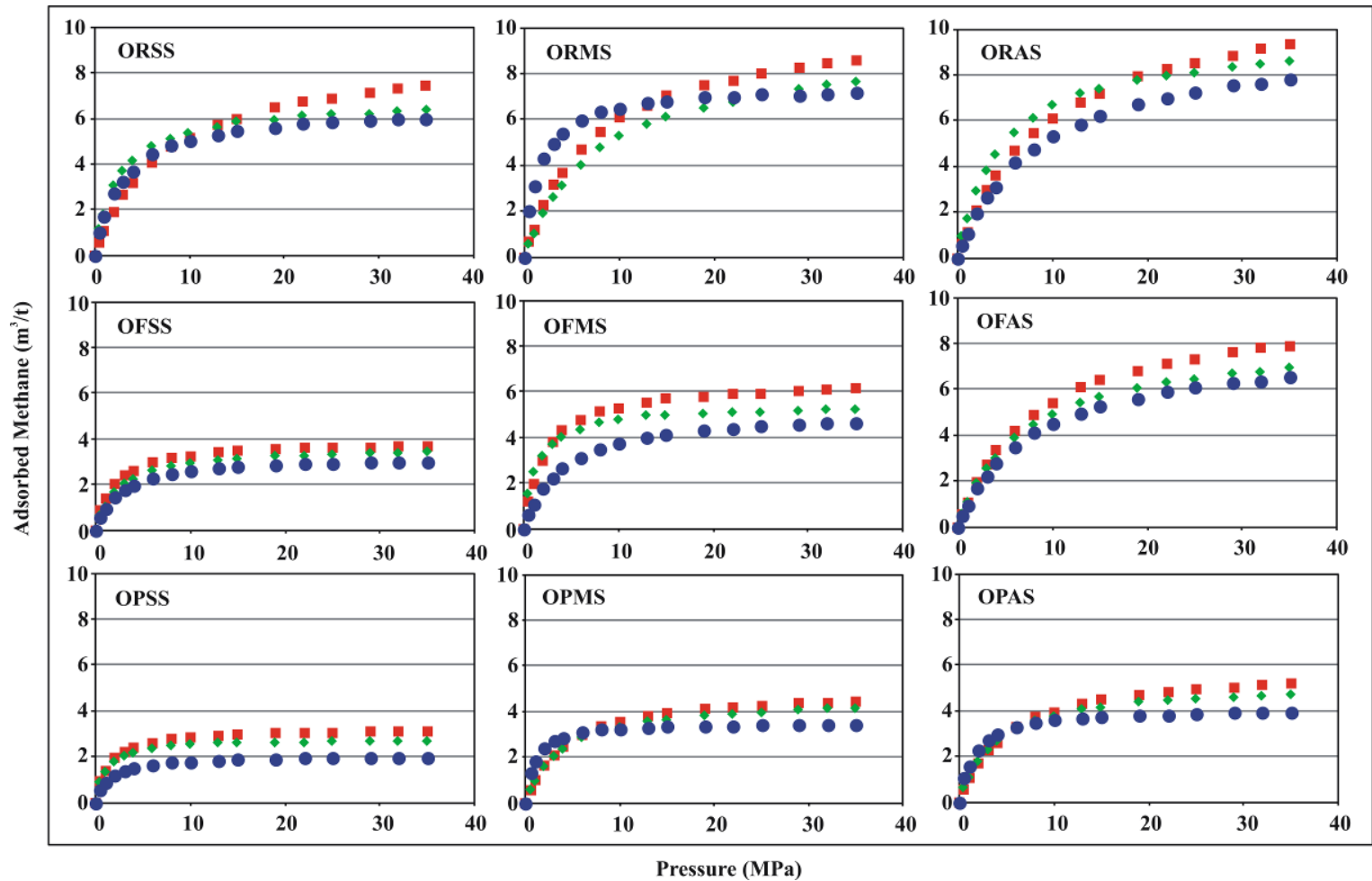

Figure 8 Shale gas adsorption capacity of the 9 types of lithofacies, showing the organic-rich argillaceous shale (ORAS) has the highest adsorption capacity.

\subsection{Effect of lithofacies association on gas storage capacity}

As discussed in the previous section, the storage capacity for absorbed gas is mainly affected by the contents of organic matter and clay minerals, and the storage capacity for free gas is mainly affected by the porosity and permeability. Due to the high content of organic matter and good porosity and permeability, ORSS has a relatively higher free gas storage capacity. Due to its high contents of organic matter and clay minerals, ORAS has a relatively higher absorbed gas storage capacity, which is also favorable for the sealing of free gas due to high clay content (Ross and Bustin., 2009). The lithofacies association of ORSS with ORAS interlayers at the bottom of the Longmaxi Formation not only provides an enormous space for free gas storage but also for absorbed gas storage (Figure 9).

A typical case is the Niobrara shale. The chalk benches interbedded with marl beds. The organicrich marls are good for hydrocarbon generation and the chalk benches are good for gas storage (Loucks and Rowe, 2014; Duhailan et al., 2015). The exploration practice in Sichuan Basin also revealed that the sandwich-like lithofacies association has a high gas content through gas desorption experiments in situ and high production after hydraulic fracturing (Guo and Zhang, 2014). Therefore, this type of lithofacies association has the highest gas storage capacity, as characterized by the highest gas content in the subsurface, and is a favorable target for the exploration and development of shale gas. 

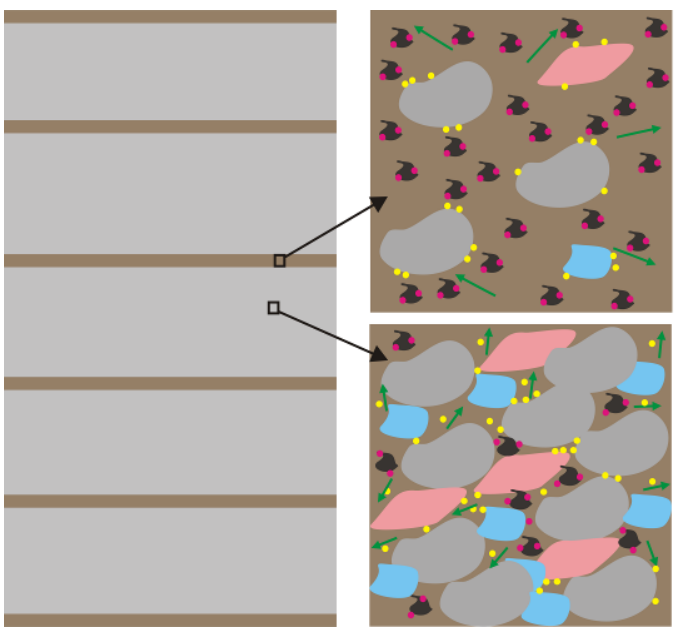

\begin{tabular}{|c|c|c|c|}
\hline & Lithofacies & ORSS & ORAS \\
\hline & $\begin{array}{l}\text { ffective Porosity } \\
\text { ange/average, } \% \text { ) }\end{array}$ & $\frac{0.11-5.61}{1.61}$ & $\frac{0.11-4.46}{1.10}$ \\
\hline & $\begin{array}{l}\text { Permeability } \\
\text { ange/average, } \mathrm{mD} \text { ) }\end{array}$ & $\frac{0.0001-0.1674}{0.0267}$ & $\frac{0.0001-0.0321}{0.0032}$ \\
\hline $\begin{array}{r}\text { Gas } \\
\text { (R }\end{array}$ & $\begin{array}{l}\text { Desorption Content } \\
\text { ange/average, } \mathrm{m}^{3} / \mathrm{t} \text { ) }\end{array}$ & $\frac{0.3-2.5}{1.6}$ & $\frac{0.5-1.6}{1.2}$ \\
\hline $\begin{aligned} \text { Adsor } \\
\quad(\mathrm{R}\end{aligned}$ & $\begin{array}{l}\text { rbed Methane Content } \\
\text { ange/average, } \mathrm{m}^{3} / \mathrm{t} \text { ) }\end{array}$ & $\frac{6.0-7.4}{6.6}$ & $\frac{7.8-9.3}{8.6}$ \\
\hline & ORSS & ORAS & Quartz \\
\hline & Feldspar & Carbonate & Clay Mineral \\
\hline 2 & Organic Matter & Adsorbed Gas & Free Gas \\
\hline
\end{tabular}

Figure 9 Diagram of sandwich-like lithofacies association and its effect on gas storage capacity and seal. ORSS has higher porosity and permeability than ORAS, but has lower adsorbed methane content than ORAS, showing ORSS are favorable for storage free gas and ORAS are favorable for gas generation, adsorption, and seal.

\section{Conclusions}

A series of description of outcrops and drilling cores, well-logging interpretation and correlation procedures, and laboratory experiments were performed to improve the classification of shale lithofacies and to investigate their effect on gas storage in the Silurian Longmaxi Formation Shale in the southeastern Sichuan Basin, China. The following key conclusions are reached:

a) Based on the content of organic matter and mineral composition, a classification of 12 shale lithofacies was proposed. Through its application in the Silurian Longmaxi Formation shale, this classification was proven to be easily understood and reasonable, and useful. A total of 9 types of lithofacies were identified in the study area, namely, ORSS, ORMS, ORAS, OFSS, OFMS, OFAS, OPSS, OPMS and OPAS. These lithofacies are of distinct features in the aspects of color, lamina, density, porosity, and permeability. Due to its high content of organic matter and quartz, ORSS has relatively good porosity and permeability, which are favorable for gas richness, hydraulic fracturing and exploitation of shale gas.

b) The bottom of the Longmaxi Formation is mainly ORSS shale lithofacies, characterized by stable lateral distribution, good connectivity, and a decrease of thickness from NW to SE. From bottom to top, the content of organic matter decreases and that of clay minerals increases, and the lithofacies gradually evolves into mixed shale and argillaceous shale from siliceous shale. The middle and upper parts of the Longmaxi Formation generally have rapid lithofacies change, characterized by various lithofacies altering, leading to poor lateral connectivity and relatively high spatial heterogeneity.

c) ORSS, ORMS and ORAS are good for gas storage capacity, but OPSS, OPMS and OPAS are not conducive for shale gas storage. ORAS has the highest methane adsorption capacity, and ORSS has the largest storage space for free gas. The lithofacies association of ORSS with ORAS interlayers was proven to be best exploration pay zone due to its positive effect on the gas storage capacity, gas generation and accumulation, and fracability. 


\section{Acknowledgments}

This research was supported by the National Science Foundation of China (No.51274068 and No.41472112), the National Basic Research Program of China (No.2014CB239105), and the Special Scientific Research Project Foundation of Ministry of Land and Resources of the People's Republic of China (No.12120114046701). The authors wish to acknowledge the Chongqing Institute of Geology and Mineral Resources for providing the drill cores used in this study. We also wish to thank Lijun Cheng, Ye Zhang, and Ningning Zhong for their earlier work about the data collection.

\section{References}

Abouelresh MO, Slatt RM. Lithofacies and Sequence Stratigraphy of the Barnett Shale in East-central Fort Worth Basin, Texas. AAPG bulletin, 2012, 96(1): 1-22.

Bowker KA. Barnett Shale Gas Production, Fort Worth Basin: Issues and Discussion. AAPG bulletin, 2007,91(4): 523-533.

Burnaman MD, Xia WW, Shelton J. Shale Gas Play Screening and Evaluation Criteria. China Petrolemu Exploration, 2009,14(3): 51-64.

Chalmers GRL, Bustin R M. Lower Cretaceous gas shales in northeastern British Columbia, Part I: geological controls on methane sorption capacity. Bulletin of Canadian petroleum geology, 2008, 56(1): 1-21.

Chen J, Xiao X. Evolution of nanoporosity in organic-rich shales during thermal maturation. Fuel, 2014, 129: 173-181.

Chen L, Lu Y, Jiang S, Li J, Guo T, Luo C. Heterogeneity of the Lower Silurian Longmaxi marine shale in the southeast Sichuan Basin of China. Marine and Petroleum Geology, 2015, 65, 232-246.

Chen S, Zhu Y, Wang H, Liu H, Wei W, Fang J. Shale gas reservoir characterisation: a typical case in the southern Sichuan Basin of China. Energy, 2011, 36(11): 6609-6616.

Dill HG, Ludwig RR, Kathewera A, Mwenelupembe J. A lithofacies terrain model for the Blantyre Region: Implications for the interpretation of palaeosavanna depositional systems and for environmental geology and economic geology in southern Malawi. Journal of African Earth Sciences, 2005,41(5), 341-393.

Du XB, Zhang MQ, Lu YC, Ping C, Lu YB. Lithofacies and depositional characteristics of gas shales in the western area of the Lower Yangtze, China. Geological Journal, 2014, doi: 10.1002/gj.2587.

Duhailan M, Sonnenberg S, Longman M. Analyzing “Beef” Fractures: Genesis and Relationship With Organic-Rich Shale Facies[C]. Unconventional Resources Technology Conference (URTEC), 2015.

Eberzin AG. Middle and Upper Pliocene of the Black Sea Region, in Statigrafiya SSSR: Neogene SSSR (Stratigraphy of the USSR: Neogene of the USSR). Moscow: Akad. Nauk SSSR, 1940, 8:477-566.

Guo TL, Zhang H. Formation and enrichment mode of Jiaoshiba shale gas field, Sichuan Basin. Petroleum Exploration and Development, 2014, 41(1): 31-40.

Hickey JJ, Henk B. Lithofacies summary of the Mississippian Barnett Shale, Mitchell 2 TP Sims well, Wise County, Texas. AAPG bulletin, 2007, 91(4): 437-443. 
Huang J, Caineng Z, Jianzhong L, Dazhong D, Sheiiao, WANG, Shiqian W, CHENG K. Shale gas generation and potential of the Lower Cambrian Qiongzhusi Formation in the Southern Sichuan Basin, China. Petroleum Exploration and Development, 2012, 39(1), 75-81.

Hughes HE, Thomas AT. Trilobite Associations, Taphonomy, Lithofacies and Environments of the Silurian Reefs of North Greenland. Palaeogeography, Palaeoclimatology, Palaeoecology, 2011, 302(3): 142-155.

Jacobi D J, Gladkikh M, LeCompte B, Hursan G, Mendez F, Longo J, Ong S, Bratovich M, Patton GL, Shoemaker P, Shoemaker P. Integrated petrophysical evaluation of shale gas reservoirs. In CIPC/SPE Gas Technology Symposium 2008 Joint Conference. Society of Petroleum Engineers, 2008.

Jarvie DM, Hill RJ, Ruble TE, Pollastro RM. Unconventional shale-gas systems: The Mississippian Barnett Shale of north-central Texas as one model for thermogenic shale-gas assessment. AAPG bulletin, 2007, 91(4), 475-499.

Jarvie DM. Total Organic Carbon (TOC) Analysis: Chapter 11: Geochemical Methods and Exploration, 1991.

Jiang Z, Tang X, Cheng L, Li Z, Zhang Y, Bai Y, Yuan Y, Hao J. Characterization and origin of the

Silurian Wufeng-Longmaxi Formation shale multiscale heterogeneity in southeastern Sichuan Basin, China. Interpretation, 2015, 3(2), SJ61-SJ74.

Lewy Z, Perelis-Grossowicz L, Dvorachek M, Ilani S. Lower Eocene Crustacean Burrows (Israel) Reflect a Change from K-to r-Type Mode of Breeding Across the KT Boundary Clarifying the Process of the End-Cretaceous Biological Crisis. INTECH Open Access Publisher, 2011:313-336. Loucks R G, Rowe H D. Upper Cretaceous Niobrara Chalk in Buck Peak Field, Sand Wash Basin, NW

Colorado: Depositional Setting, Lithofacies, and Nanopore Network[C]//SPE/AAPG/SEG Unconventional Resources Technology Conference. Society of Petroleum Engineers, 2014.

Loucks RG, Ruppel SC. Mississippian Barnett Shale: Lithofacies and Depositional Setting of a Deepwater Shale-gas Succession in the Fort Worth Basin, Texas. AAPG bulletin, 2007,91(4): 579-601.

Peters KE, Cassa MR. Applied Source Rock Geochemistry. Memoirs-American Association of Petroleum Geologists, 1994, 93-93.

Rickman R, Mullen MJ, Petre JE, Grieser WV, Kundert D. A practical use of shale petrophysics for stimulation design optimization: All shale plays are not clones of the Barnett Shale. In SPE Annual Technical Conference and Exhibition. Society of Petroleum Engineers, 2008.

Rivard C, Lavoie D, Lefebvre R, Séjourné S, Lamontagne C, Duchesne M. An overview of Canadian shale gas production and environmental concerns. International Journal of Coal Geology, 2014, 126, 64-76.

Ross D J K, Bustin R M. The importance of shale composition and pore structure upon gas storage potential of shale gas reservoirs. Marine and Petroleum Geology, 2009, 26(6): 916-927.

Sahoo AK, Mukherjee R, Mukherjee A, Mukherjee D, Srivastava M. Application of Lithofacies Modeling in Enhancing the Well Productivity; An Example From Eagle Ford Shale. In SPE/AAPG/SEG Unconventional Resources Technology Conference. Society of Petroleum Engineers, 2014. 
Schieber J, Zimmerle W. Petrography of shales: a survey of techniques. Shales and mudstones: petrography, petrophysics, geochemistry, and economic geology, 1998, 2: 3-12.

Schmoker JW. Determination of Organic-matter Content of Appalachian Devonian Shales from Gamma-ray Logs. AAPG Bulletin, 1981, 65(7): 1285-1298.

Singh P. Lithofacies and Sequence Stratigraphic Framework of the Barnett Shale, Northeast Texas, ProQuest LLC, 2008, 1-181.

Slatt RM, Molinares-Blanco C, Amorocho JD, Cabarcas CL, Torres-Parada E. Sequence Stratigraphy, Geomechanics, Microseismicity, and Geochemistry Relationships in Unconventional Resource Shales. In SPE/AAPG/SEG Unconventional Resources Technology Conference. Society of Petroleum Engineers, 2014.

Slatt RM, O'Brien NR. Pore types in the Barnett and Woodford gas shales: Contribution to understanding gas storage and migration pathways in fine-grained rocks. AAPG bulletin, 2011, 95(12): 2017-2030.

Slatt RM, Rodriguez ND. Comparative sequence stratigraphy and organic geochemistry of gas shales: Commonality or coincidence?. Journal of Natural Gas Science and Engineering, 2012, 8: 68-84.

Sondergeld CH, Newsham KE, Comisky JT, Rice MC, Rai CS. Petrophysical considerations in evaluating and producing shale gas resources. In SPE Unconventional Gas Conference. Society of Petroleum Engineers, 2010.

Tan J, Horsfield B, Fink R, Krooss B, Schulz HM, Rybacki E, Zhang JC, Boreham CJ, Van G, Tocher, BA. Shale gas potential of the major marine shale formations in the Upper Yangtze Platform, south China, Part III: Mineralogical, lithofacial, petrophysical, and rock mechanical properties. Energy \& Fuels, 2014, 28(4), 2322-2342.

Tang X, Jiang Z, Li Z, Gao Z, Bai Y, Zhao S, Feng J. The effect of the variation in material composition on the heterogeneous pore structure of high-maturity shale of the Silurian Longmaxi formation in the southeastern Sichuan Basin, China. Journal of Natural Gas Science and Engineering, 2015, 23, 464-473.

Wang G, Carr TR. Methodology of Organic-rich Shale Lithofacies Identification and Prediction: A Case Study from Marcellus Shale in the Appalachian Basin.Computers \& Geosciences, 2012, 49: $151-163$. 